Cahiers $d u$ MONDE RUSSE

\section{Cahiers du monde russe}

Russie - Empire russe - Union soviétique et États indépendants

$50 / 2-3 \mid 2009$

L'Europe orientale, 1650-1730. Crises, conflits et renouveau

\title{
A Russian Merchant's TaleDavid L. RANSEL
}

, The Life and Adventures of Ivan Alekseevich Tolchënov, Based on His Diary, Bloomington \& Indianapolis : Indiana University Press, 2009, xvi + 320 p., maps

\section{Anna Joukovskaia}

\section{(2) OpenEdition}

\section{Journals}

Édition électronique

URL : https://journals.openedition.org/monderusse/9747

DOI : 10.4000/monderusse. 9747

ISSN : $1777-5388$

Éditeur

Éditions de l'EHESS

Édition imprimée

Date de publication : 15 septembre 2009

ISBN : 978-2-7132-2260-3

ISSN : $1252-6576$

\section{Référence électronique}

Anna Joukovskaia, "A Russian Merchant's TaleDavid L. RANSEL », Cahiers du monde russe [En ligne], 50/2-3 | 2009, mis en ligne le 14 janvier 2013, consulté le 04 septembre 2022. URL : http:// journals.openedition.org/monderusse/9747 ; DOI : https://doi.org/10.4000/monderusse. 9747

Ce document a été généré automatiquement le 4 septembre 2022.

Tous droits réservés 


\section{A Russian Merchant's TaleDavid L. RANSEL}

, The Life and Adventures of Ivan Alekseevich Tolchënov, Based on His Diary, Bloomington \& Indianapolis : Indiana University Press, 2009, xvi + 320 p., maps

Anna Joukovskaia

David L. RANSEL, A Russian Merchant's Tale, The Life and Adventures of Ivan Alekseevich Tolchënov, Based on His Diary, Bloomington \& Indianapolis : Indiana University Press, 2009, xvi + 320 p., maps

1 This book is constructed as a detailed, meticulously researched biography of an eighteenth-century Russian merchant, and conceived as an exegesis of a unique source, the diary that Ivan Tolchënov kept daily between 1769 and 1812. Undoubtedly, Tolchënov was not an average representative of his socio-professional group, and the book as a whole can hardly be considered "a portrait of Russia's commercial class," as asserted on the fourth cover, though some events of the protagonist's life are presented by the author, and justly so, as illustrations of the social practices typical of the described milieu (education and professional training, marriages, etc.). Rather than presenting a collective image of a social group, David L. Ransel tackles the more ambitious task of exploring the interaction between some of the basic variables defining an individual's social self: juridical status, position in a particular social context, personal lifestyle, self-image. In this way, the biographical enterprise proves capable of producing an implosion in the standard models of social stratification and mobility.

2 Ivan Tolchënov was a merchant both in terms of status and economic profile, and he never showed any aspiration for social advancement, either for himself or his children. In this respect, the fate of his oldest son is particularly symptomatic. According to his father's wishes, Pëtr was educated in a Moscow private school. In principle, this relatively sophisticated type of education allowed one to seek entry to the state's civil 
service, which opened a prospect of ennoblement. But Ivan did not seem to have considered that option, for he married Pëtr into a merchant family and registered him as first-guild merchant.

While Tolchënov did not seek an opportunity for what historians call social mobility, the lifestyle he invented for himself gave him an eclectic social physiognomy. His life was perfectly unsurprising for a merchant son of the times. Born into an old grain-merchant family in the city of Dmitrov (some $80 \mathrm{~km}$ north of Moscow), Ivan received a standard education (Russian grammar, some arithmetic, and on-job training in family business between the ages of ten and twenty), married a Moscow merchant daughter, and became a partner of the family firm, the best of his time being occupied by business trips throughout Russia. His way of life changed drastically when, upon the death of his father, Ivan found himself in possession of a relatively important fortune. He was twenty-five, and eagerly launched out into the adventures of self-making.

Ivan built an elegant stone house, the best in the whole provincial town of Dmitrov, which he surrounded with landscape gardens adorned with exotic flowers and trees. The Tolchënov family spent the cold seasons in town and moved to the country in the summer. Neglecting the business affairs, which he almost totally delegated to hired agents who cheated him, Ivan shared his time between local politics, administration and philanthropy, and elaborate forms of leisure such as gardening, reading, keeping a diary, surveying the progress of some architectural project, or observing the sky through a telescope. In the meantime, his son lived in Moscow in a German private pension, learning foreign languages. Sincerely cherishing the religious traditions of his family, Ivan went on pilgrimages to visit famous sites and relics, but he also took his wife and children on pleasure trips to the capitals, where he indulged his taste for theater-going, prospecting for literary novelties in the Academy bookshop, hunting for rare seeds in the Dimidov famous orangeries, attending public ceremonies in which the imperial family took part, as well as services in catholic and protestant churches "out of curiosity," visiting factories, strolling down avenues and through public gardens. As to his social contacts, far from despising or ignoring his merchant relatives and relations, he also cultivated several long-lasting friendships with noblemen and entertained an aristocratic acquaintanceship. In his fine home, he organized refined dinner parties where his extended family appeared alongside with prominent clergymen, local officials and aristocrats. Many of these did not hesitate to return Ivan's invitations.

5 It took that life of cultivated interests only a decade to use up the family fortune generated by the efforts of two generations. Ivan's economic failure was due not so much to squandering as to a lack of personal attention to business. This did not come as a surprise, for Tolchënov had been consciously running into irreparable debt for several years. He clearly saw that his leisurely lifestyle was inconsistent with the busy profession of grain trader. He knew that financial decline was going to deprive him of the privileged status of first-guild merchant. Still, this man, who otherwise did not lack either practical reason or willpower, proved unable to change anything in his way of life. This moral paralysis, as well as the severe five-year-long illness that almost killed him after he was finally forced to go bankrupt, and also the fact that up to the end of his life he tried to maintain the tastes and interests that he was no more able to indulge on the former scale, all demonstrate the degree to which Tolchënov identified himself with his lifestyle. 
6 To sum it up, while willingly assuming the socially unambiguous juridical status and economic profile of a merchant, Tolchënov, by his inventive and non-conformist lifestyle, contributed to the emergence of a socially diverse urban elite of leisurely, indefatigably curious, relatively open-minded people with a taste for socializing on a basis of a shared cultural consumption.

7 The critical remarks one is tempted to make about this book concern the methodology. The author's declared intention to use the tools of microhistory seems to fall short of its aim. Ransel does pay much attention to some of the privileged objects of microhistorical studies such as sentiments, rhythms of daily life, rituals, as well as community life, family relations, etc., but his more or less cautious interpretations often turn out to be founded either on personal common sense, or on commonplaces of the standard macrohistorical narrative. For example, having indicated that Tolchënov's wife attended a pageantry in the Kremlin the day following her sister's funeral, the author suggests that she did so to find "a distraction from grief she needed after having lost a third sister within a short time" (p. 119). This purely impressionistic explanation seems insufficient for a situation where almost every element (grief and its public expression, attitude to death) deserves historical commentary. Writing about the emotional attachment to children, the author speculates that rich merchant wives did not breastfeed their babies (p. 123), while his own argument of "short birth intervals" suggests the contrary (a simple calculation shows that Tolchënov's wife, who gave birth to sixteen children in twenty years, enjoyed a mean birth interval of six months, which is quite sufficient for breastfeeding, especially if we take into account that nine of her children died under two months of age). Tolchënov's readiness to accept medical intervention during illness is, according to Ransel, the result of his "aspiration to modernity" (p. 150), although Ivan himself describes it elsewhere as a human weakness appealing the Creator's forgiveness (p. 127). Mentioning that the Tolchënov family spent its summers at the mills, Ransel asserts that they were "escaping to the countryside for relaxation" (p. 101), and they probably did, but a true microhistorical analysis would have explained, or at least asked, the questions of how and when the countryside came to be associated with relaxation, the city with stress, and whether the notion of escaping to nature could be part of Tolchënov's mentality. And even the suggestions that appear convincing, like the surprising psychological interpretation according to which Tolchënov used his pocketwatch "as present-day parents [take] a video-camera along on a vacation trip" (p. 79), lack microhistorical proof to support them.

8 Nonetheless, A Russian Merchant's Tale is an event in the historiography of Russia's ancien régime. We all know the difficulty of discerning the intricacies of life behind the documentary evidence showing isolated legal or socio-professional groups. Ransel's most important achievement in this book consists precisely in describing a sizable portion of Russian society as an integrated social body. 